\title{
MEANS OF CREATING THE ADVERTISING EFFECTS IN THE CREOLIZED TEXTS OF MARKETING COMMUNICATION
}

\author{
Olga A. Selemeneva \\ Bunin Yelets State University, Yelets, Russia
}

\begin{abstract}
The article discusses the issue of linguistic and paralinguistic means of creating some psychological techniques in marketing communication. Advertising text is considered as an example of a complex linguistic-andvisual phenomenon, which is represented by two heterogeneous parts: verbal and nonverbal. The author identifies and describes the system of means aimed at forming the effects of recipient's emotional involvement and gradually increasing attention. The study is carried out on the material of creolized commercial advertising texts published in international and Russian magazines in 2018. Verbal means of creating the effect of emotional involvement includes the words with semantic component of intellectual and aesthetic evaluation, abstract nouns, declarative exclamatory sentences and imperatives. The effect of gradually increasing the recipient's attention is achieved by using the words of utilitarian, normative and teleological evaluation, some affixal morphemes, such as: ультра-, сверх-, cynep-; adjectives in comparative and superlative degree, cardinal numerals, lexical repetitions, interrogative sentences, parceled and compressed utterances, expressive syntactic constructions and other means. On the nonverbal level, the effects of emotional experiences, and the effect of gradually increasing the recipient's attention are achieved through paralinguistic means: type variation, the combination of colours, spatial-planar variation of the text, the images.

Key words: effects of advertising, emotivity, concentration of attention, creolized text, semiotic heterogeneous components, verbal part, paralinguistic means.

Citation. Selemeneva O.A. Means of Creating the Advertising Effects in the Creolized Texts of Marketing Communication. Vestnik Volgogradskogo gosudarstvennogo universiteta. Seriya 2. Yazykoznanie [Science Journal of Volgograd State University. Linguistics], 2019, vol. 18, no. 4, pp. 105-117. (in Russian). DOI: https://doi.org/ 10.15688/jvolsu2.2019.4.8
\end{abstract}

\section{СРЕДСТВА СОЗДАНИЯ РЕКЛАМНЫХ ЭФФЕКТОВ В КРЕОЛИЗОВАННЫХ ТЕКСТАХ МАРКЕТИНГОВОЙ КОММУНИКАЦИИ}

\author{
Ольга Александровна Селеменева \\ Елецкий государственный университет им. И.А. Бунина, г. Елец, Россия
}

\begin{abstract}
Аннотация. Статья посвящена проблемам эффективной маркетинговой коммуникации. На материале креолизованных коммерческих рекламных текстов из международных и российских журналов за 2018 год ح. автором выделены и описаны средства формирования двух рекламных эффектов: эмоционального пережи₹ вания и постепенного усиления внимания. Установлено, что рассматриваемые психологические приемы создаются совокупностью словесных и несловесных (паралингвистических) средств. Эффект эмоционального переживания формируется такими вербальными средствами, как лексемы со значением интеллектуаль总 ной и эстетической оценки, абстрактные существительные, повествовательные восклицательные и имперае тивные предложения; а эффект постепенного усиления внимания достигается в результате использования Таких вербальных средств, как лексемы, выражающие утилитарную, нормативную и телеологическую оценङ ку, аффиксальные морфемы типа ультра-, сверx-, cynep-, количественные числительные, синтетические и (2) аналитические формы степеней сравнения прилагательных, свободно функционирующие предложно-па-
\end{abstract}


дежные конструкции, вопросительные предложения, экзистенциальные предложения, парцеллированные, расчлененные и компрессивные высказывания, лексические повторы. Невербальными средствами создания эффектов эмоционального переживания и постепенного усиления внимания являются шрифтовое варьирование, определенная комбинаторика, динамика и гармония цветов, пространственно-плоскостная синтагматика, изображения. Показано, что невербальные средства создания рассматриваемых эффектов могут быть самостоятельными и вспомогательными (по отношению к языковым средствам).

Ключевые слова: эффект рекламы, эмоциональность, напряжение внимания, креолизованный текст, семиотически гетерогенные компоненты, вербальная часть, паралингвистические средства.

Цитирование. Селеменева О. А. Средства создания рекламных эффектов в креолизованных текстах маркетинговой коммуникации // Вестник Волгоградского государственного университета. Серия 2, Языкознание. - 2019. - Т. 18, № 4. - С. 105-117. - DOI: https://doi.org/10.15688/jvolsu2.2019.4.8

\section{Введение}

В последние десятилетия лингвистика все чаще обращается к всестороннему исследованию взаимосвязей и взаимодействия естественного языка с другими семиотическими системами. Тем целостным в функционально-структурном и смысловом плане образованием, которое соединяет семиотически гетерогенные компоненты, становится креолизованный текст. Интерес к изучению осложненных текстов, обладающих высоким прагматическим потенциалом и информационной емкостью, возникает как вследствие неоднозначности решения проблемы делимитации границ текста, так и под влиянием амбивалентных медийных глобализационных процессов. Именно их действие обеспечивает распространение новых информационнокоммуникационных технологий, «интернетизацию» традиционных средств коммуникации, изменение способов дистрибуции медиапродуктов, определяет приоритеты и стратегии рекламной деятельности. Поэтому прототипичными образцами поликодовых текстов становятся современные рекламные тексты, в которых целостность всего негомогенного феномена, транслирование реципиенту общего смысла, реализация механизмов манипуляции и внушения обеспечивается интеграцией вербальных и иконических элементов, максимальной сбалансированностью языковых и неязыковых средств.

Цель нашей работы - проанализировать с опорой на комплексный подход рекламные тексты как особые семиотические объекты, выявить и описать вербальные и невербальные средства создания некоторых рекламных эффектов в них: эффекта эмоционального пе- реживания и эффекта постепенного усиления внимания.

Понятие «эффект рекламы» связано с изучением психолингвистических и прагмалингвистических аспектов маркетинговой коммуникации, базирующихся на интерпретации идеи об антропоцентричности языка и признании его полифункциональности. Тематическое поле отечественных и зарубежных исследований в этой области еще недостаточно широко. Однако уже имеются работы, описывающие приемы, способствующие реализации суггестивной стратегии рекламного дискурса (гиперболы, ориентационные и пространственные метафоры, императивы и др.) [Вариясова, 2013]; механизмы манипулятивного воздействия в гендерно ориентированной рекламе с целью создания соответствующего имиджа товара [Колтышева, 2008]; конкретные универсальные и специфические манипулятивные тактики, трансформирующие прототипический рекламный текст [Попова, 2005]; речевые стратегии и импликации рекламных объявлений [Liu Fang, 2012; McQuarrie, Mick, 1996] и некоторые другие явления.

Обычно термин «рекламный эффект» определяют как «сильное впечатление, произведенное кем-либо или чем-либо» [Кохтев, 1991, с. 59]. Уточняя эту дефиницию, мы рассматриваем в качестве рекламных эффектов группу психологических приемов, основанных на внушении и влияющих на массовое потребительское поведение. Постановка проблемы текстовой гетерогенности и изучение рекламного текста как явления, существующего в специфической «изобразительно-вербальной форме» [Максименко, 2012, с. 97], позволяет констатировать факт формирования рекламных эффек- 
тов во взаимодействии вербального и невербального компонентов текста.

Материалом исследования послужили креолизованные коммерческие рекламные тексты из международных и собственно российских журналов за 2018 год ${ }^{2}$. Обращение к такого рода источнику языкового материала обусловлено несколькими причинами. Во-первых, эти источники отражают существенное влияние западной рекламы на русский рекламный дискурс и регулярную обновляемость правил построения рекламного текста и средств речевого воздействия на реципиентов. Во-вторых, высокое полиграфическое качество перечисленных журналов, нацеленность на создание специфического визуального пространства за счет использования особых изобразительных средств и возможностей современного фотоискусства позволяют собрать для анализа коммерческие рекламные тексты с разной степенью креолизации и характером взаимодействия между компонентами. В-третьих, ориентация перечисленных журналов на продуцирование стиля жизни различных социальных и гендерных групп, их жизненной философии и способов коммуникации предопределяет тематическую дифференцированность рекламных текстов, особенности их строения, функции паралингвистических средств.

В методологической основе работы лежат два подхода к рекламному дискурсу: системный, базирующийся на принципе единства лингвистической и экстралингвистической сторон речи, и семиотический, актуализирующий идею коммуникативной эффективности текстов, поликодовых по своей природе. При интерпретации и систематизации авторской картотеки примеров, включающей более 600 единиц, применялись описательно-аналитический и коммуникативно-прагматический методы, метод контекстного анализа.

\section{Вербальные и невербальные средства реализации эффекта эмоционального переживания}

Одной из характерных черт рекламного текста является эмоциональность; она проявляется даже в тех случаях, когда реклама как будто бы апеллирует к разуму человека, ис- пользуя метод убеждения в преимуществах рекламируемого продукта. По словам Д.В. Ольшанского, «на деле такое информационное воздействие реально оказывается лишь камуфляжем» [Ольшанский, 2002, с. 317].

В рекламном дискурсе эффект эмоционального переживания как психологический прием основан и на способности человека испытывать эмоции при восприятии предмета или ситуации (радость, симпатию и др.), и на способности к социоэмоциональному взаимодействию, то есть восприятию, пониманию эмоциональных состояний других субъектов, адекватному реагированию на них. Поэтому условно эффект эмоционального переживания складывается из собственно эмоционального переживания и сопереживания.

Характерной чертой креолизованных текстов рекламы является реализуемая вербальным компонентом оценочная модальность. На лексическом уровне для ее создания используются преимущественно имена прилагательные. Эффект эмоционального переживания в основном создается общеоценочным прилагательным хороший и его синонимами с разными экспрессивно-стилистическими оттенками: безукоризненный, безупречный, великолепный, восхитительный, замечательный, идеальный, изумительный, лучший, особенный, отличныци, превосходный, солидный и др. Они называют не один признак рекламируемого объекта, а ряд свойств и выражают «холистическую оценку, аксиологический итог» [Арутюнова, 1988, с. 75]. Например:

(1) Приходите в CLUEV взглянуть на одну из лучших в Европе коллекцию камней... (TATLER, 2018, № 5, с. 45);

(2) Идеальные украшения для такой разной тебя в новой осенней коллекции PANDORA (COSMOPOLITAN. Русское издание, сентябрь 2018, c. 37);

(3) Превосходная развлекательная программа для детей и взрослых (Гастрономъ, 2018, № 78 , c. 87).

Для создания эффекта эмоционального переживания в рекламный текст вводятся имена прилагательные (в том числе возникшие путем адъективации причастий), выражающие различную оценку, связанную с 


\section{РАЗВИТИЕ И ФУНКЦИОНИРОВАНИЕ РУССКОГО ЯЗЫКА}

удовлетворением нравственного чувства и чувства прекрасного, составляющих, по словам Н.Д. Арутюновой, «ядро духовного начала человека» [Арутюнова, 1988, с. 76]: психологическую (интеллектуальную) оценку (захватывающий, интересный, сложный, увлекательный и др.), эстетическую оценку (живописныци, красивыци, прекрасныц̆, невероятный и др.). Например:

(4) Это уникальная возможность стать частью постоянно развивающейся истории города и открыть новую захватывающую главу в своей жизни (TATLER, 2018, № 5, c. 69);

(5) Лето в горах - это всегда новые впечатления и эмоции, невероятные виды, ароматы горных трав и заряд энергии каждый день! (TATLER, 2018, № 5, c. 103).

Иррадиируя на весь рекламный текст, оценочная лексика заменяет логическую аргументацию и вызывает у реципиента устойчивые положительные ассоциации.

Благоприятный эмоциональный фон формируют и абстрактные существительные со значением психологических состояний субъекта, положительных эмоций, отвлеченных свойств, качеств, способности человека действовать в соответствии со своими интересами, целями (удовольствие, радость, счастье, ностальгия, роскошь, молодость, свобода, великолепие и др.). Например:

(6) ...Ведь наблюдать в больших окнах рассветы и закаты с видом на башни Московского Кремля - сплошное удовольствие (TATLER, 2018, № 4, c. 109);

(7) Ощутите полную свободу творчества с современными объективами NIKKOR Z... (Вокруг света, 2018, № 10, с. 9);

(8) Все великолепие дворцов в вашем доме (Интерьерный, 2018, № 27, с. 17);

(9) Интрига. Желание. Страсть. Наслаждение. Это - новая коллекция ароматов HFC (VOUGE, 2018, № 11, c. 127).

На синтаксическом уровне эффект эмоционального переживания создается в результате использования повествовательных восклицательных и побудительных предложений. Восклицательные предложения обладают особой эмоциональной напряженностью и создают экспрессивность рекламного текста. Например:
(10) МАХЕЕВЬ. Делает мир вкуснее! (Гастрономъ, 2018, № 5-6, с. 45);

(11) Традиция! Ремесло! Совершенство! Сыр Gruyиre AOP Швейцария - девятивековая традиция сыроварения (Гастрономъ, 2018, № 10, с. 9).

(12) Сборная ŠKODA Hockey Edition готова побеждать! (За рулем, 2018, № 10, с. 19);

(13) Эффекс Трибулс делает мужчину успешным! Ваш «Эффекс» - Ваш успех! (Вокруг света, 2018, № 11, c. 29).

Восклицательная интонация, усиливая смысловое содержание рематической части высказывания, позволяет ему в полной мере реализовать воздействующую функцию. В результате человек, по мнению Д.В. Ольшанского, «начинает ощущать себя членом некой виртуальной общности “эмоционально-позитивных” людей» [Ольшанский, 2002, с. 316], у него повышается самооценка.

Побудительные предложения, сформированные глаголами повелительного наклонения, выполняют свое основное назначение - обеспечивают прескрипцию определенного поведения человека-потребителя, ориентацию на выполнение действия-приобретения объекта рекламы. В анализируемых нами коммерческих рекламных текстах директивные речевые акты в основном представляют советы, предложения, рекомендации, которые позволяют сократить дистанцию между адресантом и адресатом и сформировать благоприятный эмоциональный фон. Например:

(14) Окружи себя облаком туалетной воды на основе теплых пряных и искрящихся цветочнофруктовых нот (COSMOPOLITAN. Русское издание, сентябрь 2018, с. 41);

(15) Volkswagen Polo. Двигайся вместе с городом (Вокруг света, 2018, № 10, с. 7).

Использование преимущественно глагольных форм единственного числа, как объясняют С.С. Ваулина и И.Ю. Кукса, обусловлено желанием составителей рекламы создать атмосферу «личностного общения и вызвать доверие к адресанту» [Ваулина, Кукса, 2018, с. 71].

Встречается в рекламных текстах и побуждение, основанное на обязательности осуществления выраженного в предложении действия, передающегося путем использования модального слова нужно в сочетании с инфинитивом: 
(16) Шторы нужно покупать в цвет своей души! (Жилая среда, 2018, № 10, с. 21).

В эмоционально окрашенных побудительных предложениях, ориентирующих реципиента на преодоление препятствий на пути к желаемой цели, транслируется активная жизненная позиция, воссоздается ситуация успеха. Например:

(17) Стань красивой! Закажи себе коробочку Лизабокс на сайте lisa.ru/box (Мой ребенок, 2018, № 11, c. 89);

(18) Стань первым среди лучших! (За рулем, 2018, № 10, c. 2).

Эффективность рекламного текста зависит не только от тщательного отбора языковых средств, но и от выбора невербальных средств, способных актуализировать благоприятный эмоциональный фон. Так, на формирование положительных эмоций по отношению к какому-либо объекту рекламы оказывают влияние самостоятельные паралингвистические средства - фотографии-изображения женщин, детей и животных. В рекламных текстах приоритетно использование фотографий женских лиц, что свидетельствует об актуализации архетипа женщины как способа привлечения непроизвольного внимания и, следовательно, рождения аффективного эмпатического отклика, активизации в сознании реципиента идеального представления, ассоциирующегося с рекламируемым объектом.

Желание вызвать у реципиента умиление и удовлетворить эстетические потребности в гармонии и красоте обусловливает использование изображений в жанре портрета или бытовой фотографии, целью которой является передача эмоционального состояния объекта съемки. Например, Дмитрий Дибров с женой и сыновьями, распаковывающими подарки, в рекламе интернет-магазина игрушек «TOY.RU» (TATLER, 2018 , № 1, с. 50) или улыбающаяся Лив Тайлер, бегущая с дочерью Лулой по пляжу, в рекламе курортных отелей «Maxx Royal Resorts» в Tyрции (TATLER, 2018, № 1, с. 44-45).

Цвет в креолизованных коммерческих рекламных текстах также участвует в формировании эмоций. Используемая в рекламе цветовая гамма рассчитана не только на эстетическое воздействие, но и на определен- ный психоэмоциональный отклик, формирование правильного настроя, основанного на чувстве удовлетворения, погружения в состояние расслабления или, напротив, напряжения, трепета, взволнованности. Как пишет Г. Цойгнер, «выразительность цвета должна согласовываться с функцией или назначением предмета или с определенной тематикой» [Цойгнер, 1971, с. 112]. Несмотря на то что существует национально-культурная специфичность символики и восприятия цвета, в анализируемых текстах она нивелируется за счет большого количества международной рекламы. В ней красный цвет ассоциируется с активностью, волей, энергией, страстью: аромат «POWER of SEDUCTION» от «ANTONIO BANDERAS» (Домашний очаг, сентябрь 2018, с. 10) или четвертый аромат из коллекции «Narciso eau de parfum rouge» (Домашний очаг, сентябрь 2018, c. 29); серый - с властью, зрелостью, сдержанностью: реклама спорткара «Prototype 10» от японского автопроизводителя «Infiniti» (ТестДрайв, 2018, № 10, с. 4-5) или шин «Hankook» (За рулем, 2018, № 10, с. 2); желтый - с теплом, солнцем, движением: женская одежда из Германии «MADELEINE» (Домашний очаг, сентябрь 2018, с. 19); зеленый - обилием, здоровьем, природой, расслаблением: натуральная косметика из Израиля «ORGANIX COSMETIX» (КРАСОТА и ЗДОРОВЬЕ, 2018, № 5 , с. 109) или акустические кабинки от компании «ALCOPA PROJECT» (Жилая среда, 2018 , № 10, с. 7); голубой и синий - с небом, легкостью, изяществом: реклама ювелирных бутиков «GRAFF» и «BULGARI» (TATLER, 2018 , № 1, с. 4, 8); белый - с чистотой, молодостью, сиянием: реклама модного дома «CHANEL» и ювелирного японского бренда «MIKIMOTO», специализирующегося на создании украшений из жемчуга (TATLER, 2018, № 1, с. 12, 16), или крема «Возраст эксперт» от «L'ORÉAL» (Домашний очаг, сентябрь 2018 , с. 35) и т. д.

Г. Цойгнер различал три ступени выбора цвета с позиций эстетики: комбинаторика (абстрактная группировка цветов для создания определенного ощущения), гармония (выбор сочетания цветов с учетом их воздействия) и динамика (выбор цвета с ориентацией на психофизиологическое воздействие) [Цойгнер, 1971, с. 108]. В письменных реклам- 


\section{РАЗВИТИЕ И ФУНКЦИОНИРОВАНИЕ РУССКОГО ЯЗЫКА}

ных текстах учитываются все эти ступени. Например, сочетание красного (самого активного цвета спектра) с белым является «жестким» сочетанием, вызывает сильную активацию эмоционального состояния и используется преимущественно в креолизованных текстах, объект рекламы которых предполагает ярко выраженный сексуальный подтекст или нацеленность на борьбу с чем-либо: помада «DIORROUGE» (на белом фоне изображен красный футляр помады, модель в красном пуловере, с красным маникюром и яркокрасными губами) (COSMOPOLITAN, сентябрь 2018, с. 2); крем «Ultimune Концентрат» от «SHISEIDO» для восстановления кожи и предотвращения ее старения (красный флакон с кремом на красно-белом фоне) (COSMOPOLITAN, сентябрь 2018, с. 31) и др. Разнообразные цветовые сочетания могут активизировать или компенсировать эффект эмоционального переживания, иными словами, подчеркивать или ослаблять его.

\section{Вербальные и невербальные средства формирования эффекта постепенного усиления внимания}

Задача любого рекламного текста состоит в том, чтобы привлечь и удержать внимание адресата в процессе чтения. Чтобы избежать затухания внимания, копирайтеры используют эффект постепенного усиления внимания. Под указанным эффектом мы понимаем психологический прием, нацеленный на аттракцию и удерживание напряжения внимания реципиента в письменном рекламном тексте за счет содержательного, логико-эмоционального и визуального усиления информационных блоков.

Эффект постепенного усиления внимания формируется как вербальными, так и невербальными средствами, причем языковые средства его создания более разнообразны по сравнению со средствами, формирующими эффект эмоционального переживания. На лексическом уровне используется оценочная лексика: прилагательные со значением утилитарной (вредный, выгодный, полезный, удобный и др.), нормативной (здоровый, качественнылй, классический, правильный, нестандартный, популярный, индивидуальный, инно- вационныцй и др.) и телеологической оценки (неэффективный, эффективный, результативный, нерезультативный и др.). Такие прилагательные, по мнению Н.Д. Арутюновой, «связаны с практической деятельностью, практиче-скими интересами и повседневным опытом человека» [Арутюнова, 1988, с. 76-77], они участвуют в выстраивании логической аргументации через индукцию и дедукцию в рекламном сообщении. Прилагательные нормативной оценки актуализируют достоинства рекламируемых объектов, а утилитарной и телеологической оценки - акцентируют внимание реципиента на получаемой потребительской выгоде. В результате их использования происходит содержательное усиление информации вербальной части креолизованных рекламных текстов. Например:

(19) Большой выбор специальной строительной химии и уникальных материалов поможет решить вам даже самую сложную задачу (Калининградские дома, 2018, № 10, с. 2);

(20) Качественное международное образование - инвестиция в будущее вашего ребенка (TATLER, 2018, № 5, с. 75);

(21) L-карнозин - самый эффективный омолаживающий компонент из известных науке на сегодняшний день (Домашний очаг, сентябрь 2018, с. 57).

Актуализации эффекта усиления внимания способствуют абстрактные отглагольные имена существительные со значением действий, имеющих положительный результат: замедление, восстановление, улучшение, снижение, уменьшение, укрепление и под. Например:

(22) Карнозин Эвалар способствует... быстрому восстановлению после физических нагрузок, улучшению работы мозга и сердца... (Домашний очаг, сентябрь 2018, с. 57);

(23) Восстановление структуры волос с экстрактом водоросли Ундария Перистая и гидролизованного Кератина (Домашний очаг, сентябрь 2018, c. 107).

Такие существительные указывают на факт, а не доказывают его. Привлекая внимание реципиента к рекламируемому объекту посредством представления аргумента как аксиомы, они выполняют аттрактивную функцию и тем самым способствуют формирова- 
нию эффекта усиления внимания в креолизованных текстах.

В создании указанного эффекта могут участвовать некоторые аффиксальные морфемы (префиксы типа ультра-, сверх-, супер-), благодаря которым дериваты имеют значение крайней степени проявления того, что названо мотивирующим словом. Например:

(24) Созданная силой моря, улучшенная биологами Biotherm, теперь энергия преображения красной водоросли заключена в ультралегкой текстуре инновационного крема для лица (Домашний очаг, сентябрь 2018, с. 13);

(25) Суперэкономичная морозильная камера с классом А++/А-60\% (Гастрономъ, 2018, № 7-8, с. 2);

(26) Витамин для сверхспособностей (Вокруг света, 2018, № 10, с. 29).

Эффект постепенного усиления внимания достигается благодаря использованию прилагательных в сравнительной и превосходной степени. Выражая максимальное проявление свойств рекламируемого объекта, они способствуют формированию его положительной оценки. Например:

(27) Новый KIA Cerato поднимет оценку ваших достижений на еще более высокий уровень (За рулем, 2018, № 10, с. 4);

(28) Рыбная лавка КАМЧАТКА. Только дикая рыба и вкуснейшая икра (Калининградские дома, 2018, № 10, c. 69);

(29) Становись моложе с каждым днем! (Домашний очаг, сентябрь 2018, с. 57);

(30) Наиболее эффективный карабин с продольно-скользящим затвором... (Охота и рыбалка XXI век, 2018, № 7, с. 99).

Производные слова с элементами типа ультра-, сверх-, супер- и прилагательные в сравнительной и превосходной степени - яркий пример манипуляций копирайтеров с искусственными скрытыми сравнениями. Эти языковые средства направлены на представление преимуществ рекламируемого объекта, создание неповторимого образа, удерживание внимания потенциального покупателя в письменном тексте.

Заметную роль в создании эффекта постепенного усиления играют порядковые и количественные числительные. Из порядковых числительных наиболее последователь- но аттрактивную функцию выполняет числительное первый. Например:

(31) ПЕРВЫЙ МИЦЕЛЛЯРНЫЙ уход для волос (Домашний очаг, сентябрь 2018, с. 39);

(32) Первое тональное средство Clarins в текстуре сыворотки (COSMOPOLITAN. Русское издание, сентябрь 2018, с. 23);

(33) Первый легко усваиваемый «Куркумин» (Гастрономъ, 2018, № 10, с. 63).

Количественные числительные, записанные цифрами в целях компрессии текстовой информации и с учетом ориентации на зрительное восприятие текста реципиентом, участвуют в создании эффекта усиления внимания при использовании в маркированных списках. В этих случаях они берут на себя роль «маячков», помогающих структурировать сложную информацию в целях упрощения ее восприятия. Например:

(34) Через 4 недели:

$97 \%$ Кожа увлажнена

$90 \%$ Улучшение общего состояния кожи

81 \% Сведены к минимуму проблемы с кожей

$93 \%$ Заметный эффект сияния

$86 \%$ Более ровный тон кожи

95 \% Гладкая кожа (COSMOPOLITAN. Pycское издание, сентябрь 2018, с. 33).

Употребленные однократно или вне маркированного списка, количественные числительные, на наш взгляд, создают не столько эффект усиления внимания, сколько эффект доверия - психологический прием, заключающийся в формировании у реципиента уверенности в достоверности представленной в рекламе информации. Основными средствами создания этого эффекта выступают антропонимы (Лив Тайлер, Наталья Водянова, Оксана Федорова и др.) и показатели авторизации (Как отмечает Татьяна Валерьевна...), позволяющие осуществить суггестию через авторитетный источник информации. Помимо указанных средств, созданию эффекта доверия способствуют количественные числительные, которыми оперируют копирайтеры с целью ввести статистические данные, полученные в результате проведенных измерений, экспериментов. Если эта фактуальная информация не является достоверной, она все же выполняет свою основную функцию: у адресата 


\section{РАЗВИТИЕ И ФУНКЦИОНИРОВАНИЕ РУССКОГО ЯЗЫКА}

создается впечатление точности и полноты полученного знания.

Для формирования эффекта усиления внимания в рекламный тест вводится и наречие впервые. Оно выносится в начало предложения:

(35) Впервые в лабораториях VICHY в MINERAL 89 минерализирующую термальную воду в рекордной концентрации [89 \%] объединили с увлажняющим компонентом натурального происхождения - гиалуроновой кислотой в высокой концентрации (COSMOPOLITAN. Русское издание, сентябрь 2018, с. 75);

(36) Секреты детокса со всего света. Проверено временем. Впервые перед вами (ELLE, 2018, № 11, c. 121).

Эффект усиления внимания формируется не только лексическими, но и синтаксическими средствами. Так, его созданию способствуют предложения, осложненные однородными членами. Цепочки однородных членов помогают удержать внимание адресата за счет подробности описания рекламируемых объектов, перечисления их типов или свойств. Связь в сочиненных рядах часто осуществляется только при помощи интонации или слов типа и многое другое, $и$ подобное, которые указывают на незаконченность сочиненных рядов, возможность их дополнения. Например:

(37) Инновации для пола: плетеный винил, гибридный кварц-винил, пробка с фотопечатью, микодур и многое другое (Калининградские дома, 2018, № 10, с. 35);

(38) Уменьшите видимые признаки старения. Подтянутая, гладкая, сияющая кожа (Домашний очаг, сентябрь 2018, с. 13);

(39) Различные объективы, окуляры, разрешения матриц, крепления и насадки позволяют выбрать оптимальную конфигурацию тепловизора для реализации конкретного решения (Охота и рыбалка XXI век, 2018, № 7, с. 5).

С целью привлечения внимания реципиента, включения его в диалог в креолизованных рекламных текстах используются вопросительные предложения. Среди них отмечаем наличие двух типов конструкций: предложения с прямым вопросительным значением и предложения с переносным вопросительным значением (подробно о типах вопросительных значений см.: [Воейкова, 2015]). Прямое значение реализуется в прямых вопросах с эксплицитными или имплицитными ответами. Например:

(40) Что нужно знать о вызревании? Вызревание (созревание, выдержка) говядины - подготовка мяса к употреблению. В процессе вызревания происходят естественные изменения, в результате которых оно делается мягче и вкуснее (Гастрономъ, 2018, № 9, с. 5)

(41) Устали от усталости? (Гастрономъ, 2018, № 9, c. 9);

(42) Любишь хоккей и автомобили? (Вокруг света, 2018, № 11, с. 13)

В примере (40) представлен развернутый ответ на вопрос, в примерах (41) и (42) подразумевается краткий ответ «да/нет». Переносное вопросительное значение реализуется в конструкциях, имеющих риторический характер:

(43) WINTER. Что еще нужно? (Движок, 2018, № 68 , c. 55 ).

Вопросительные структуры в вербальной части креолизованных коммерческих рекламных текстов могут быть оформлены расчлененно:

(44) Что старит нас в первую очередь? Морщины? Нечеткий овал? (ELLE, 2018, № 5, с. 219);

(45) Кашель? Бронхит? Лекарственный растительный препарат Бронхипрет (Мой ребенок, 2018, № 11, c. 75).

Такие свернутые формы синтаксических построений, представляющие именные синтагмы, ориентированы на динамизм и предполагают максимальную словесную сжатость при сохранении смысловой емкости. Они являются результатом влияния разговорной речи и, как показано А.А. Воейковой, «приобретают еще и оттенок дополнительной эмоциональности (удивления, изумления, сочувствия)» [Воейкова, 2015, с. 115], приводящей к логико-эмоциональному усилению вербальной части рекламного текста.

Заметную роль в создании эффекта усиления внимания в текстах рекламы играет группа экзистенциальных предложений. При необходимости привлечь внимание реципиента к месту нахождения рекламируемого 
объекта или явления копирайтеры используют конструкции, представленные именительным падежом существительного и включающие локативные словоформы. Например:

(46) Летняя палитра в Гранд Паласе (Я покупаю, июль-август 2018, с. 27);

(47) Удобное место в центре города (Интерьерный, 2018, № 27, с. 15);

(48) Премьера в России (Вокруг света, 2018, № 11, c. 31).

Однако пространственный локализатор не всегда вербально представлен в высказывании. Он может отсутствовать по причине смысловой избыточности, возникающей вследствие упоминания в контексте или восстановления из ситуации. При этом существительное в именительном падеже распространяется атрибутивными словоформами, подчеркивающими уникальные характеристики товара. Например:

(49) Просторные учебные классы с инновационным оборудованием (TATLER, 2018, № 5, с. 75);

(50) Сверхэффективные инновационные природные комплексы (Вокруг света, 2018, № 11, с. 81).

В рекламе школ международного оператора «Brookes Education Group» (пример 49) легко восстанавливается пространственный локализатор - в школе; в рекламе пищевых добавок от «Siberian Welliness» (пример 50) - пространственный локализатор - в этом препарате.

Экзистенциальные предложения без усложнения синтаксиса позволяют повысить возможности запоминания рекламного текста и его экспрессивность за счет своей фрагментарности и семантической емкости.

Стилистической напряженности, усилению логических и смысловых акцентов способствует употребление парцеллированных конструкций, в которых парцелляты, отрываясь от базовой части высказывания, поясняют, семантически распространяют основное рекламное сообщение. Например:

(51) Сражение с акне. Но не с кожей (COSMOPOLITAN. Русское издание, сентябрь 2018, c. 191);

(52) Абсолютно натуральный продукт, только из Швейцарии. Не содержит глютен и лактозу (Гастрономъ, 2018, № 10, с. 9);
(53) Было время, когда люди разучивали танцевальные движения. Когда одеваться стильно было «классной» идеей. Когда хороший дизайн был актуален десятилетиями (Вокруг света, 2018, № 11, c. 3).

Таким образом, эффект постепенного усиления внимания формируется посредством расчлененности структуры рекламного текста, которая проявляется не только в парцеллированных, но и сегментированных конструкциях, включающих две части: препозитивный номинатив, называющий объект рекламы, и характеризующий его компонент. Например:

(54) Greenfield. Чай в алюминиевых капсулах. Jardin. Кофе в алюминиевых капсулах (Вокруг света, 2018, № 11, с. 44 45);

(55) LOLA KONTI. Мультибрендовый бутик (Я покупаю, сентябрь 2018, с. 9);

(56) CALVIN KLEIN WOMEN. Новый аромат для нас (ELLE, 2018, № 11, с. 71).

Использование латинской графики препозитивного номинатива - прагматонима, идентифицирующего товар или вид услуг, - выполняет аттрактивную функцию, активизирует, по мнению И.В. Высоцкой, метаязыковое поведение посредством актуализации противопоставления «своего» и «чужого» [Высоцкая, 2010, c. 473], а также восприятия иноязычного слова как более престижного.

Требования смысловой емкости и словесной сжатости, стремление к компактности рекламного текста обусловливают распространение компрессивных структур - предложений с нулевыми сказуемыми. Например:

(57) Beauty spa by World Class. Красота - pядом (TATLER, 2018, № 2, с. 71);

(58) БИОТИН для визуального эффекта плотности, КОЛЛАГЕН - для укрепления, КОФЕ - для поднятия волос у корней и активизации их роста (Glamour, 2018, № 6, c. 79).

Добиться повышенного внимания адресата к ключевым характеристикам объекта рекламы позволяют предложно-падежные формы в самостоятельном употреблении. Например:

(59) Интерьерная мастерская RAPPA DECO. От дизайн-проекта до реализации (Калининградские дома, 2018, № 10, с. 55); 


\section{РАЗВИТИЕ И ФУНКЦИОНИРОВАНИЕ РУССКОГО ЯЗЫКА}

(60) Лечение гриппа и простуды в полном объеме! Для взрослых и детей с 6-ти месяцев (Домашний очаг, сентябрь 2018, с. 139);

(61) Все. От мебели до посуды (TATLER, 2018, № 4, c. 89);

(62) LACOSTE. Для нее. Для него (COSMOPOLITAN. Русское издание, сентябрь 2018, c. 45);

(63) От головля до форели (Спортивное рыболовство, 2018, № 9, с. 21).

Реализации эффекта усиления внимания в рамках сложного синтаксического целого способствуют лексические повторы ключевых слов. Например:

(64) Много лет LUZAR выпускает автомобильные радиаторы. Мы являемся лидерами по объему выпуска автомобильных радиаторов в России и странах бывшего СССР. Для нас вершина производственного мастерства - это выпуск радиаторов для грузовых автомобилей. Это направление является сложным и требующим отдельного подхода - в сравнении с выпуском «обычных» легковых и легко-грузных теплообменников. Мы гордимся тем, что система качества LUZAR позволяет производить крупногабаритные радиаторы - для автомобилей КАМАЗ, МАЗ, ЛиАЗ... - несомненно высочайшего качества и ресурса. Мы понимаем, насколько важно, чтобы Ваш грузовик бесперебойно работал. Именно поэтому мы производим радиаторы, обладающие высочайшим качеством и ресурсом - чтобы Ваша работа не останавливалась, и Ваш труд приносил еще больше пользы людям (Движок, 2018, № 68, с. 53).

Ключевые слова радиаторы, автомобильный, грузовой, качество, LUZAR, мы, Bаш выступают, во-первых, структурными показателями глобальной и локальной связности приведенного рекламного текста, а во-вторых, способствуют реализации «формулы внушения» (подробно о формуле см.: [Вариясова, 2013, с. 16]). Используемые ключевые слова хорошо знакомы потенциальному покупателю, поэтому их повторение не приводит к вербальной сатиации или словесному насыщению, нейтрализующим эффект усиления внимания.

Помимо лексических повторов, указанный эффект поддерживается сопоставительными отношениями между отдельными высказываниями текста или предикативными единицами сложного предложения и таким сти- листическим приемом, как синтаксический параллелизм. Например:

(65) Салициловая кислота выравнивает текстуру кожи, органическая розовая вода придает сияние, а полифенол виноградных косточек контролирует выработку себума (COSMOPOLITAN. Русское издание, сентябрь 2018, с. 103);

(66) ROLEX. Эталон современных часов с 1945 года. Их функциональность и дизайн выдержали испытание временем. Эти часы не просто показывают время. Они рассказывают историю (VOUGE, 2018, № 11, c. 32).

Среди паралингвистических средств способом стимулирования интереса к бренду и удержания внимания потенциального покупателя становится использование в качестве иконического компонента фотографий известных мужчин и женщин (актеров театра и кино, певцов, врачей, ученых и др.), обладающих требуемыми личностными характеристиками и сформировавшейся репутацией. Например, Татьяна Лютаева, заслуженная артистка России, в рекламе процедуры «CoolSculpting» в клинике «Supernova» (TATLER, 2018, № 1, с. 101) или Штефан Хипп, глава и владелец «HIPP GROUP», в рекламе продуктов для детского питания «HIPP ORGANIC» (Мой ребенок, 2018, № 11, c. 41). Полагаем, что создание эффекта усиления внимания - вторичная функция таких изображений, а основная - формирование эффекта доверия, осуществление суггестии через «свидетельство».

Поскольку на непроизвольное внимание адресата влияет совокупность факторов (интенсивность раздражителя, его уникальность и др.), на невербальном уровне креолизованного рекламного текста эффект усиления внимания формируется в результате использования такого средства неязыковой письменной коммуникации, как шрифтовое варьирование, воздействующий потенциал которого основан на размере букв. Графические выделения отдельных букв, морфем или слов, словосочетаний способствуют логико-эмоциональной интенсификации содержания вербальной части рекламного текста. Например:

(67) ЧТО стало С утром НА серебряном дожде? (Вокруг света, 2018, № 10, с. 93); 
(68) ШВАБРА с инновационным легким отжимом (Коллекция. Караван историй, 2018, № 10, с. 91).

Шрифтовое варьирование наиболее важного для рекламного текста языкового элемента способствует актуализации графической игры, нацеленной на создание смысла с помощью технических ресурсов.

Супраграфемика, как показано Е.Б. Кургановой, нередко приводит к различного рода графическим искажениям - контаминациям с выделенным сегментом, порождающим «второй смысловой ряд» и позволяющим установить причинно-следственные отношения [Курганова, 2004, с. 103]. Такие искажения представлены и в нашем материале, например:

(69) ХОФИТОЛ. Отличное решение для уДАЧНОГО пищеварения. Раствор может приниматься у детей ЛЮБОГО ВОЗРАСТА! (Домашний очаг, сентябрь 2018, с. 129).

Лексема уДАЧНОГО в рекламном контексте членится на два сегмента: «у» и «ДАЧНОГО», подчеркивая связь не с мотивирующим удача, а со словом дача (УДАЧНОГО при вычете $У$ превращается в ДАЧНОГО). Этот графический прием привлечения внимания реципиента подкрепляется и изобразительным компонентом - идиллической сценой приготовления счастливой семьей блюда на мангале.

Функцию усиления внимания в тексте выполняют и графические англо-русские гибриды, активизирующие словообразовательную игру с латиницей:

(70) ОБЩАЙТESS! Выбери свою территорию общения и обменяй TESS-коины на ПРИЗЫ! (Домашний очаг, сентябрь 2018, с. 87).

Использование конечных цветов ахроматического ряда - черный шрифт на белом фоне или белый шрифт на черном фоне - также выступает средством создания эффекта усиления внимания, поскольку гармония цветов основана на факторе контрастности, обусловливающем психические реакции человека. По нашим наблюдениям, цветовой лаконизм становится характерной чертой тех креолизованных текстов, в которых рекламируемый объект символизирует утонченность, строгость, аристократизм. Например, белый фон и черный шрифт используется в рекламе одежды и аксессуаров итальянского дома моды «PRADA» (TATLER, 2018, № 2, с. 3) и французского модного дома «CHANEL» (TATLER, 2018, № 2, с. 3-4) или, наоборот, черный фон и белый шрифт в рекламе коллекции ювелирных изделий «Giardini Segreti» итальянского бренда «Pasquale Bruni» (TATLER, 2018, № 1, с. 15).

Для создания эффекта усиления, помимо шрифтового варьирования, применяется такое паралингвистическое средство, как топографемика. Пространственно-плоскостное варьирование акцентирует внимание реципиента на наиболее важных элементах текста. Например, наименования объектов рекламы обычно выделяют жирным шрифтом и располагают вверху или внизу страницы по центру.

\section{Заключение}

Проведенный анализ фактического материала из международных и российских журналов позволяет сделать вывод о том, что формирование эффектов эмоционального переживания и постепенного усиления внимания осуществляется в креолизованных текстах коммерческой рекламы посредством оптимальной сочетаемости словесных и несловесных средств. К языковым средствам создания описываемых эффектов мы отнесли оценочную лексику, абстрактные существительные, некоторые морфемы и морфологические формы, определенные типы предложений, а к наиболее активным и влияющим на аудиторию паралингвистическим средствам - фотографии, сочетаемость цветов и шрифтовое варьирование. По отношению к языковым средствам паралингвистические могут быть как относительно самостоятельными (фотографии), так и зависимыми, вторичными (шрифтовое, пространственно-плоскостное варьирование). При минимализации словесного элемента на привлечение внимания потенциальной аудитории и формирование положительного эмоционального фона нацелены изображения, самостоятельные и вспомогательные паралингвистические средства; при значительном объеме словесного компонента ведущую роль в формировании эффектов эмоционального переживания и усиления внимания играют языковые средства. 


\section{РАЗВИТИЕ И ФУНКЦИОНИРОВАНИЕ РУССКОГО ЯЗЫКА}

Выявленный набор средств формирования анализируемых психологических приемов в рекламных текстах не является исчерпывающим, он может быть расширен в результате изучения пунктуационного варьирования, необычной орфографии, сегментации текста и некоторых других особенностей, оказывающих определенное суггестивное воздействие на реципиента. Проведенное нами исследование имеет перспективы, поскольку роль креолизованных текстов возрастает в связи с изменяющимся потребностями современного общества, интенсификацией обмена информацией, качественной трансформацией коммуникации.

\section{ПРИМЕЧАНИЯ}

1 Здесь и далее в примерах орфография и пунктуация рекламных текстов сохранены.

${ }^{2}$ Источниками для отбора фактического материала послужили следующие журналы: «Вокруг света», «Гастрономъ», «Движок», «Домашний очаг», «Жилая среда», «За рулем», «Интерьерный», «Калининградские дома», «КАРАВАН историй», «КРАСОТА и ЗДОРОВЬЕ», «Мой ребенок», «Охота и рыбалка XXI век», «Спортивное рыболовство», «Тест-Драйв», «Я покупаю», «COSMOPOLITAN. Русское издание», «ELLE», «Glamour», «TATLER», «VOUGE».

\section{СПИСОК ЛИТЕРАТУРЫ}

Арутюнова Н. Д., 1988. Типы языковых значений : Оценка. Событие. Факт. М. : Наука. 341 с.

Вариясова Е. В., 2013. Средства речевого воздействия в русских рекламных текстах : автореф. дис. ... канд. филол. наук. Сургут. 24 с.

Ваулина С. С., Кукса И. Ю., 2018. Лингвистические стратегии реализации побудительной модальности в политическом лозунге и рекламном слогане // Вестник Волгоградского государственного университета. Серия 2, Языкознание. Т. 17, № 2. С. 63-73. DOI: https://doi.org/ 10.15688/jvolsu2.2018.2.7.

Воейкова А. А., 2015. Структурно-функциональные особенности вопросительных предложений (на примере текстов русской рекламы) // Вестник Томского государственного педагогического университета. Вып. 6 (159). C. 113-117.

Высоцкая И. В., 2010. «Свое» и «чужое», или Взаимодействие кириллицы и латиницы в совре- менном рекламном тексте // Вестник Нижегородского университета им. Н.И. Лобачевского. № 4 (2). С. 471-474.

Колтышева Е. Ю., 2008. Манипулятивное воздействие в современном рекламном тексте: на материале англоязычных глянцевых журналов для женщин : дис. ... канд. филол. наук. Ярославль. $281 \mathrm{c.}$

Кохтев Н. Н., 1991. Десять эффектов рекламы // Русская речь. № 6. С. 59-64.

Курганова Е. Б., 2004. Игровой аспект в современном рекламном тексте. Воронеж : Родная речь. $122 \mathrm{c}$.

Максименко О. И., 2012. Поликодовый vs. креолизованный текст: проблема терминологии // Вестник Российского университета дружбы народов. Серия: Теория языка. Семиотика. Семантика. № 2. С. 93-102.

Ольшанский Д. В., 2002. Психология масс. СПб. : ПИТЕР. $368 \mathrm{c}$.

Попова Е. С., 2005. Рекламный текст и проблемы манипуляции : дис. ... канд. филол. наук. Екатеринбург. $256 \mathrm{c.}$

Цойгнер Г., 1971. Учение о цвете (популярный очерк) / пер. с нем. Э. Н. Зеликиной ; науч. ред. Г. Г. Борис. М. : Изд-во лит. по стр-ву. 194 с.

Liu Fang, 2012. A Study of Principle of Conversation in Advertising Language // Theory and Practice in Language Studies. Vol. 2, no 12. P. 2619-2623. URL: http://www.academypublication.com/ issues/past/tpls/vol02/12/22.pdf(date of access: 09.08.2018).

McQuarrie E. F., Mick D. G., 1996. Figures of Rhetoric in Advertising Language // Journal of Consumer Research. Vol. 22, no. 4. P. 424-438. URL: http:// www.jstor.org/stable/2489791 (date of access: 12.07.2018)

\section{REFERENCES}

Arutyunova N.D., 1988. Tipy yazykovykh znacheniy: Otsenka. Sobytie. Fakt [Types of the Language Meanings: Evaluation. Event. Fact]. Moscow, Nauka Publ. 341 p.

Variyasova E.V., 2013. Sredstva rechevogo vozdeystviya $v$ russkikh reklamnykh tekstakh: avtoref. dis. ... kand. filol. nauk [Means of Speech Influence in Russian Advertising Texts. Cand. Philol. Sci. Abs. Diss.]. Tyumen. 54 p.

Vaulina S.S., Kuksa I.Yu., 2018. Lingvisticheskie strategii realizatsii pobuditelnoy modalnosti v politicheskom lozunge i reklamnom slogane [Linguistic Strategies and Realization of Incentive Modality in Political Slogan and Advertising Slogan]. Vestnik Volgogradskogo 
gosudarstvennogo universiteta. Seriya 2, Yazykoznaniye [Science Journal of Volgograd State University. Linguistics], vol. 17, no. 2, pp. 63-73. DOI: https://doi.org/10.15688/jvolsu2.2018.2.7.

Voyeykova A.A., 2015. Strukturno-funktsionalnye osobennosti voprositelnykh predlozheniy (na primere tekstov russkoy reklamy) [Structural and Functional Characteristics of Question Patterns Found in Russian Advertisements]. Vestnik Tomskogo gosudarstvennogo pedagogicheskogo universiteta [Tomsk State Pedagogical University Bulletin], iss. 6(159), pp. 113-117.

Vysotskaya I.V., 2010. "Svoe» i «chuzhoye», ili Vzaimodeystvie kirillitsy i latinitsy v sovremennom reklamnom tekste ["Own" and "Alien" (Interaction of the Cyrillic and Latin Script in Modern Advertising Text)]. Vestnik Nizhegorodskogo universiteta im. N.I. Lobachevskogo [Vestnik of Lobachevsky University of Nizhni Novgorod], no. 4 (2), pp. 471-474.

Koltysheva E.Yu., 2008. Manipulyativnoe vozdeystvie $v$ sovremennom reklamnom tekste: na materiale angloyazychnykh glyantsevykh zhurnalov dlya zhenshchin: dis. ... kand. filol. nauk. [Manipulative Influence in the Modern Advertising Text: On the Material of English Glossy Magazines for Women. Cand. Philol. Sci. Diss]. Yaroslavl. $281 \mathrm{p}$.

Kokhtev N.N., 1991. Desyat effektov reklamy [Ten Advertising Effects]. Russkaya rech, no. 6, pp. 59-64.
Kurganova E.B., 2004. Igrovoy aspekt v sovremennom reklamnom tekste [Gaming Aspect of the Modern Advertising Text]. Voronezh, Rodnaya rech Publ. 122 p.

Maksimenko O.I., 2012. Polikodovyy vs. kreolizovannyy tekst: problema terminologii [Polycode vs. Creolized Text: Terminology Problem]. Vestnik Rossiyskogo universiteta druzhby narodov. Seriya: Teoriya yazyka. Semiotika. Semantika [RUDN Journal of Language Studies. Semiotics and Semantics], no. 2, pp. 93-102.

Olshanskiy D.V., 2002. Psikhologiya mass [Mass Psychology]. Saint Petersburg, PITER Publ. 368 p.

Popova E.S., 2005. Reklamnyy tekst i problemy manipulyatsii: dis. ... kand. filol. nauk. [Advertising Texts and the Issue of Manipulation. Cand. Philol. Sci. Diss.]. Yekaterinburg. 256 p.

Tsoygner G., 1971. Uchenie o tsvete (populyarnyy ocherk) [Doctrine of Colour (Popular Essay)]. Moscow, Izdatelstvo literatury po stroitelstvu. $194 \mathrm{p}$.

Liu Fang, 2012. A Study of Principle of Conversation in Advertising Language. Theory and Practice in Language Studies, vol. 2, no. 12, pp. 26192623. URL: http://www.academypublication.com/ issues/past/tpls/vol02/12/22. pdf (accessed 9 August 2018).

McQuarrie E.F., Mick D.G., 1996. Figures of Rhetoric in Advertising Language. Journal of Consumer Research, vol. 22, no. 4, pp. 424-438. URL: http:// www.jstor.org/stable/2489791 (accessed 12 July 2018).

\section{Information about the Author}

Olga A. Selemeneva, Doctor of Sciences (Philology), Professor, Department of the Russian Language, Russian Teaching Methodology and Document Science, Bunin Yelets State University, Kommunarov St., 28, 399770 Yelets, Russia, ol.selemeneva2011@yandex.ru, https://orcid.org/0000-0002-0488-8428

\section{Информация об авторе}

Ольга Александровна Селеменева, доктор филологических наук, профессор кафедры русского языка, методики его преподавания и документоведения, Елецкий государственный университет им. И.А. Бунина, ул. Коммунаров, 28, 399770 г. Елец, Россия, ol.selemeneva2011@yandex.ru, https://orcid.org/0000-0002-0488-8428 